\title{
Excision and tension-free primary closure of pilonidal disease
}

\author{
Mohamed A. Alkatta(iD), Abdallah Mejally(iD) \\ Sana'a University, Medical Surgery, Sana'a, Yemen
}

\section{ABSTRACT}

Objective: This study aimed to estimate simple excision and tension free primary closure and to study its effectiveness in terms of operating and healing time, duration of hospital stay, degree of post operation complications, and rate of recurrence.

Material and Methods: This is study included 78 patients, of whom 71 were (91\%) males and 7 (9\%) females, who underwent excision and tension free closure. The procedure was based on bilateral side flaps, which were released and dissected $2-3 \mathrm{~cm}$ from the edge of the wound. Patient's age, gender, body mass index, wound healing, operation, drain removal, length of hospital stay, and complications and recurrence were analysed.

Results: The study involved 78 patients, 71 (91\%) males and 7 (9\%) females. Median age of the patients was 28.5 years. Mean operation time was 44.6 minutes . Sixty-one patients (78.2\%) had full primary healing without any complication. No one had hematoma or seroma, but five (6.4\%) cases had a minor wound infection and three (3.8\%) obese patients developed recurrence. Mean length of hospital stay was 2.5 days, most patients went back to their work within 3 weeks. Median follow-up period was in a 26.2 weak range (1-51.4 weak). Five (6.41\%) cases had wound infection and three (3.85\%) developed recurrence.

Conclusion: Excision and tension free primary closure were found to be simple procedures associated with lower rates of wound infection, shorter hospital stay, lower recurrence, early wound recovery and short period of being absent from work. Surgery can be easily performed and preferred for cases of non-recurrent pilonidal sinus and cyst.

Keywords: Pilonidal, primary closure, natal cleft sinus, cyst

Cite this article as: Alkatta MA, Mejally A. Excision and tension-free primary closure of pilonidal disease. Turk J Surg 2019; 35 (4): 278-284.

Corresponding Author

Mohamed A Alkatta

E-mail: drkatta2002@yahoo.com

Received: 16.11 .2018

Accepted: 04.01.2019

Available Online Date: 16.12 .2019

O Copyright 2019 by Turkish Surgical Society Available online at www.turkjsurg.com

DOI: $10.5578 /$ turkjsurg. 4368

\section{INTRODUCTION}

Pilonidal sinus (PNS) is a chronic inflammatory disease associated with excessive hair growth around the infected area and can cause anxiety, perplexity and absence from work. It was first described by Hodges in 1880 (1). It mostly exists in the natal spilt of the sacrococcygeal region and it manifests like inflammation, pus discharge and sinus formation $(2,3)$.

Onset of PNS is scarce both before adulthood and after the age of forties. Males are influenced more by this disease than females, which may be due to their more hairy nature than females (4).

Even though the progress in medical research and study, the tactic to control the pilonidal sinus illness is not well defined yet. However, the therapy regimen must perfectly decrease soreness, provide a shorter hospital stay, reduce complications and rate of recurrence, and show quick healing and return to normal life (5).

A lot of surgical procedures have been used in the caring of the pilonidal sinus disease. Incision and drainage, excision and recovery by second intention are the most commonly used practical methods $(6,7)$, whereas, there are procedures like excision and tension free primary closure, excision with reconstructive flap techniques (8), and other less prevalently used technical methods include phenol injection, cryosurgery and electro cauterization $(9,10)$. Our aim in this study was to estimate the technique, the excision of the pilonidal sinus or cyst, and examine its efficiency to reduce operating period, time of healing, and the duration of hospital stay, the degree of postoperative complications and recurrence rate. 


\section{MATERIAL and METHODS}

Seventy-eight patients suffering from un-complicated pilonidal sinus or cyst with an age ranging between 18 to 39 years participated in this prospective study. The patients were admitted to hospital from January 2013 to May 2016. Before starting our study, approval from the ethics committee of our hospital was obtained, and informed consent was taken from each patient, and their parents or partner were informed about the aim and the nature of the study, and written consent was obtained. Patient age, gender, body mass index, wound healing time, operation times, length of hospital stay, drain removal time, complications, and recurrence rates were analyzed.

\section{Surgical Procedure}

Simple excision and tension- free primary closure were performed and involved the following steps:

- Antibiotics in the form of Metronidazole (Flagyl, Sanofi-Aventis, Paris, France,) or clindamycin (Vanconex-Cp, Venus Remedies Limited, Baddi.H.P., India) And ceftriaxone (Forsef, Bilim pharmaceuticals, Maslak -Istanbul Turkey) were given to the patient half an hour before the operation.

- When the patient was placed under full anesthesia, he/she was put in the Jack-Knife position to expose the inter gluteal cleft, which was the main site of the operation. The gluteus muscles on both sides were abducted by adhesive strips of plaster stuck to the sides of the operation table. Probing and methylene blue (methylene blue, Navi Mumbai, Maharashtra, India) injection through the opening of the sinus to delineate the main tract and its side branches if present were done (Figure 1).

- Through the elliptical vertical wide incision, excision of the sinus tracts or cyst was performed and the dissection was continued down to the posterior sacral fascia (Figure 2).

- To avoid closure of the defect under tension, bilateral side flaps including skin layers and subcutaneous tissues were dissected

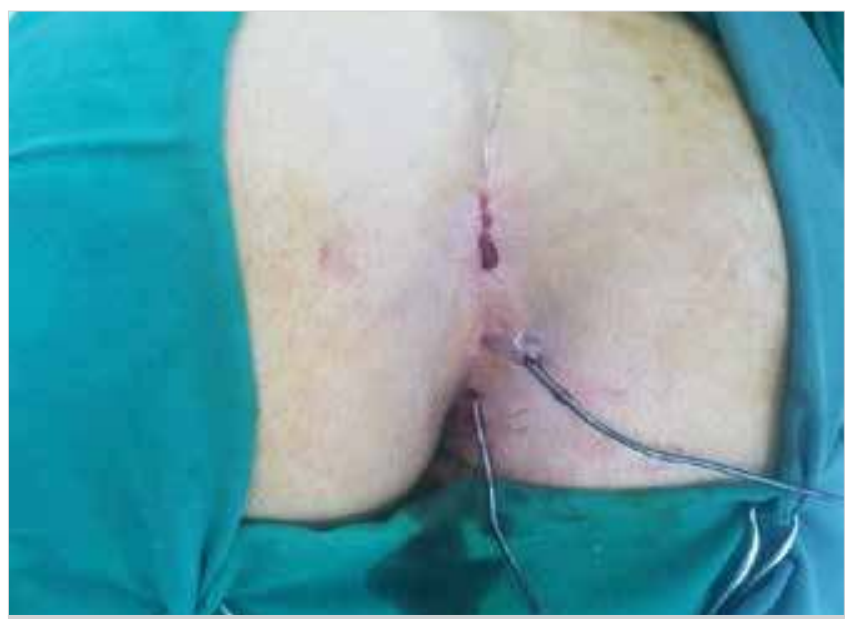

Figure 1. Probing and methylene blue injection through the opening of the sinus to delineate the main tract and its side branches if present.

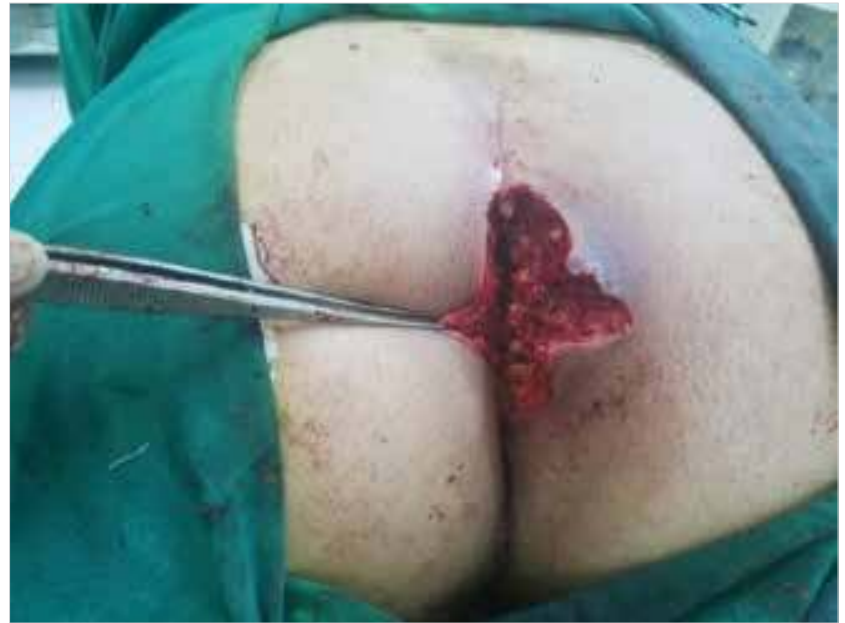

Figure 2. Excision of the sinus tracts or cyst and dissection was continued down to the posterior sacral fascial.

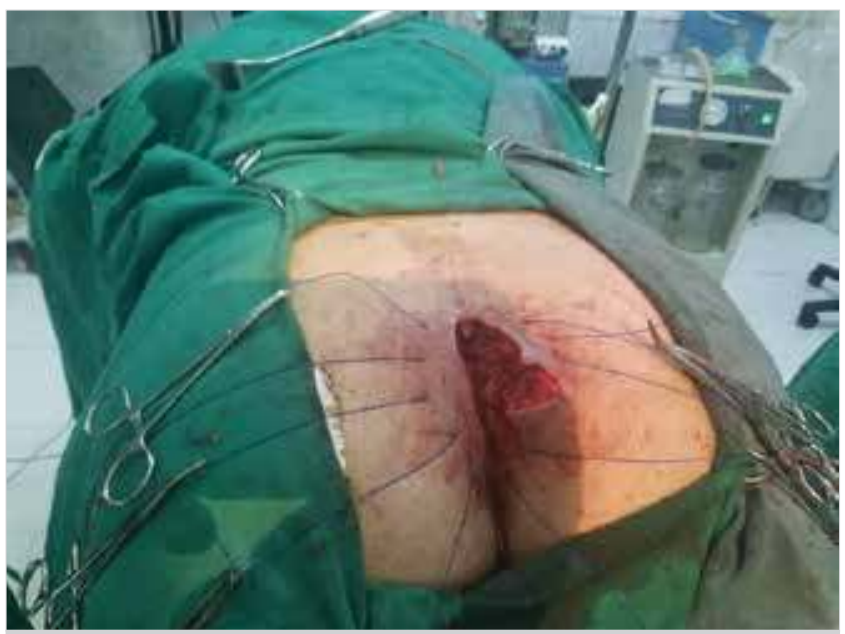

Figure 3. Bilateral side flaps including the skin and subcutaneous tissues were dissected, elliptical intradermal incision.

and cut $2-3 \mathrm{~cm}$ from the edge of the elliptical wound down to the posterior sacral fascia and gluteus maximus muscle fibers with meticulous hemostasis (Figure 3).

- The residual cavity was obliterated by 1-Prolene sutures (POIYGLYCOLIC ACID, Yancheng Huida Medical Instrument Co., Ltd, China) which were taken through the skin, subcutaneous tissue and post sacral fascia (Figure 4).

- A second vertical mattress suture 2-0 silk (silk braided, Yancheng Huida Medical Instrument Co., Ltd, China) was taken to close the gap between the Prolene stitches. Closure must be tension free to prevent dehiscence of the wound and be flat as much as possible to avoid the development of intergluteal cleft, which is the site of sinus recurrence (Figure 5).

Our practice is to put a small suction drain in the depth of the residual cavity to tighten the long threads of the Prolene sutures rolled above. Povidone -iodine (Umod, ine YMCO, Medical Indus- 


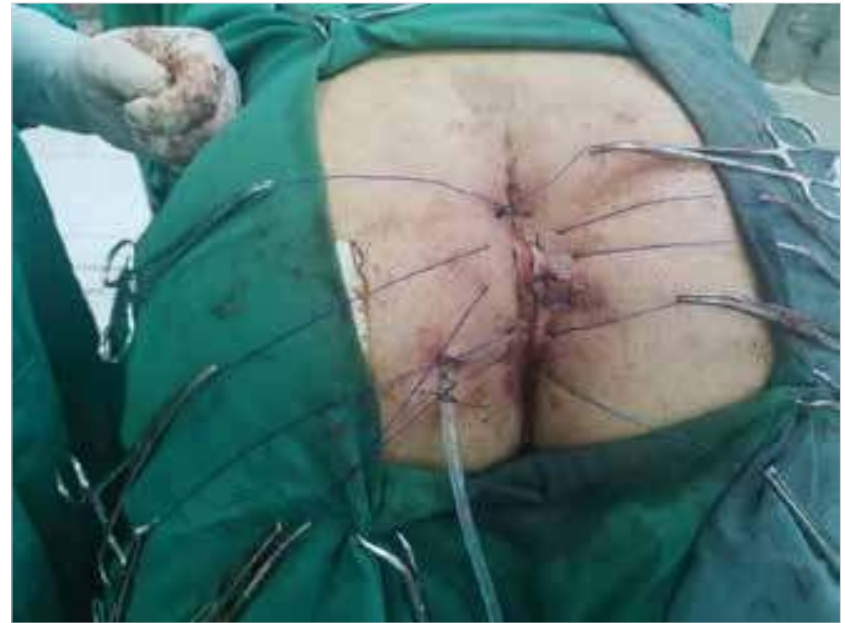

Figure 4. The residual cavity was obliterated by 1-Prolene sutures.

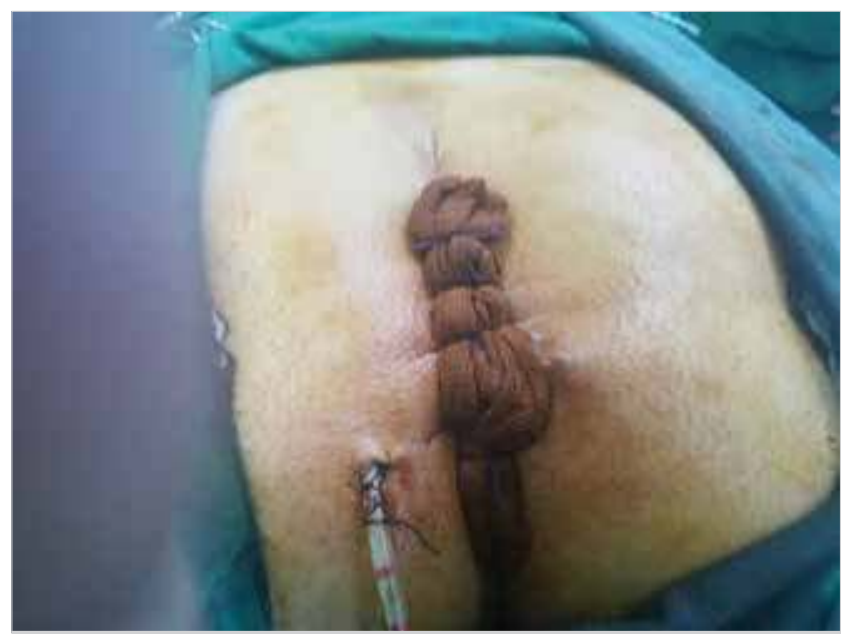

Figure 5. Closing the gap. Closure must be tension free to prevent dehiscence of the wound.

tries, Yemen) soaked gauze dressing was placed over the closed wound to provide some external pressure in an attempt to obliterate the potential space and to prevent the formation of seroma or hematoma. Post-operatively, the patients nursed were advised to sleep on one side and encouraged to mobilize early.

The suction drains were removed after 24-72 hours postoperatively depending on the amount of drainage, which must be less than $10 \mathrm{ml}$ during the last 24 hours. Antibiotics were given pre and postoperatively for 5 days in the form of Metronidazole (Flagyl, Sanofi-Aventis, Paris, France,) or vancomycin (vancomycin, Boisar, Dist-Thane, India), and Ceftriaxone (Forsef, Blim pharmaceuticals, Maslak -Istanbul, Turkey) for 24 hours and replaced by amoxicillin-clavulinate (MAGMA, ALPHA-Aleppo pharmaceutical industries, Syria) and metronidazole for 4 days. All patients were discharged after two to three days of the operation, the sutures and rolled-in compressive gauze packing were removed 2 weeks after the operation. (Figure 6).

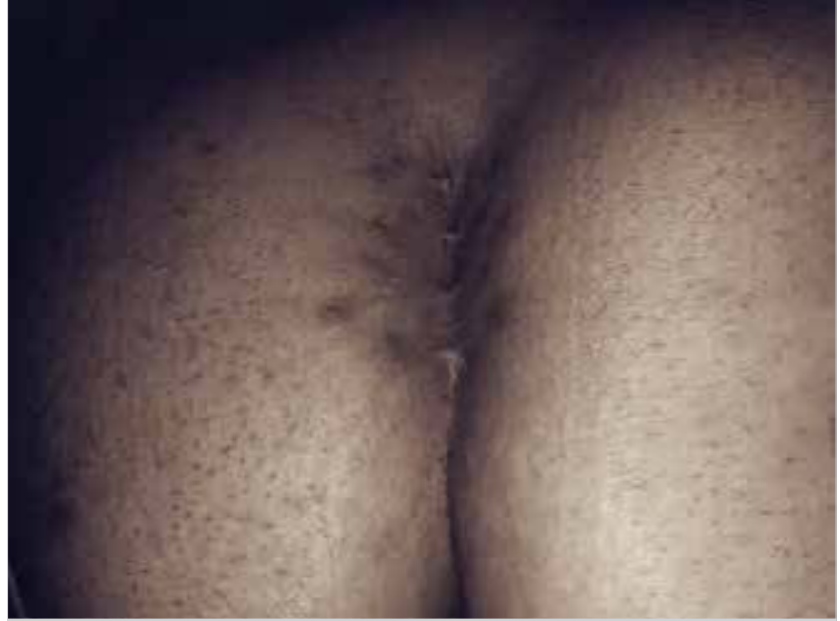

Figure 6. Postoperative picture.

\begin{tabular}{|l|c|}
\hline \multicolumn{2}{|l|}{ Table 1. Operative data } \\
\hline & Range \\
\hline Operative time* & $44.6(42-57)$ minutes \\
\hline Hospital stay* & $2.5(2-3)$ days \\
\hline Drain removal ${ }^{* *}$ & $48(24-72)$ hours \\
\hline Suture removal & 2 weeks \\
\hline Flow up time** & 26.2 weeks (1 week -12 \\
& months) \\
\hline${ }^{*}$ Mean (range), ${ }^{* *}$ Median (range). & \\
\hline
\end{tabular}

Postoperative follow-up was once per week for the first 4 weeks and then at three, 6 and 12 months from the date of the operation (Table 1).

\section{Analytical Statistic Data}

Statistical Package for the Social Sciences program (SPSS) ver. 20 (SPSS Inc., Chicago, IL, United State of America) for Windows 7.0 computer software was used for statistical analysis. Data were described in the form of frequency, mean, median, percentage (\%) and average.

\section{RESULTS}

This study included 78 Patients, 71 (91\%) males and 7 (9\%) females. Median age of the patients was 28.5 years, ranging between 18-39 years. Thirty-one (39.7\%) of the patients was overweight with a BMI between $25-30 \mathrm{~kg} / \mathrm{m}^{2}$, and $19(24.3 \%)$ patients were obese with a body mass index of over $30 \mathrm{~kg} / \mathrm{m}^{2}$ according to the classification of the World Health Organization of Obesity (11). Fourteen (17.9\%) were males and $5(6.4 \%)$ were females. Thirty-eight (48.7\%) males had excessive hair (Table 2). The occupation of the patients mainly involved accounting and computer technologies working for more than 8 hours daily in $37(47.4 \%)$ cases and long-distance driver more than 8 hours dai- 
Table 2. Preoperative patient characteristic

\begin{tabular}{|l|c|c|}
\hline \multirow{2}{*}{ Clinical presentation } & \multicolumn{2}{|c|}{ Number of patients (\%) } \\
\hline \multirow{2}{*}{ Gge* } & \multicolumn{2}{|c|}{$28.5(18-39)$} \\
\hline \multirow{2}{*}{ Obesity } & Male & $71(91 \%)$ \\
\cline { 2 - 3 } & Female & $7(9 \%)$ \\
\cline { 2 - 3 } & Overweight & $19(24.3 \%)$ \\
\cline { 2 - 3 } & Non-obese & $14(17.9 \%)$ \\
\hline \multirow{2}{*}{ Hair density in the area } & Excessive hair & $38(57.8 \%)$ \\
\cline { 2 - 3 } & Non-excessive & $40(51.3 \%)$ \\
\hline *Median (range), (\%) percentage. & \multicolumn{2}{|c|}{} \\
\hline
\end{tabular}

\section{Table 3. Modes of presentation}

\begin{tabular}{|l|c|}
\hline Clinical presentation & Number of patients (\%) \\
\hline Pain & $16(20.5 \%)$ \\
\hline Discharge & $53(67.95 \%)$ \\
\hline Abscess & $9(11.5 \%)$ \\
\hline
\end{tabular}

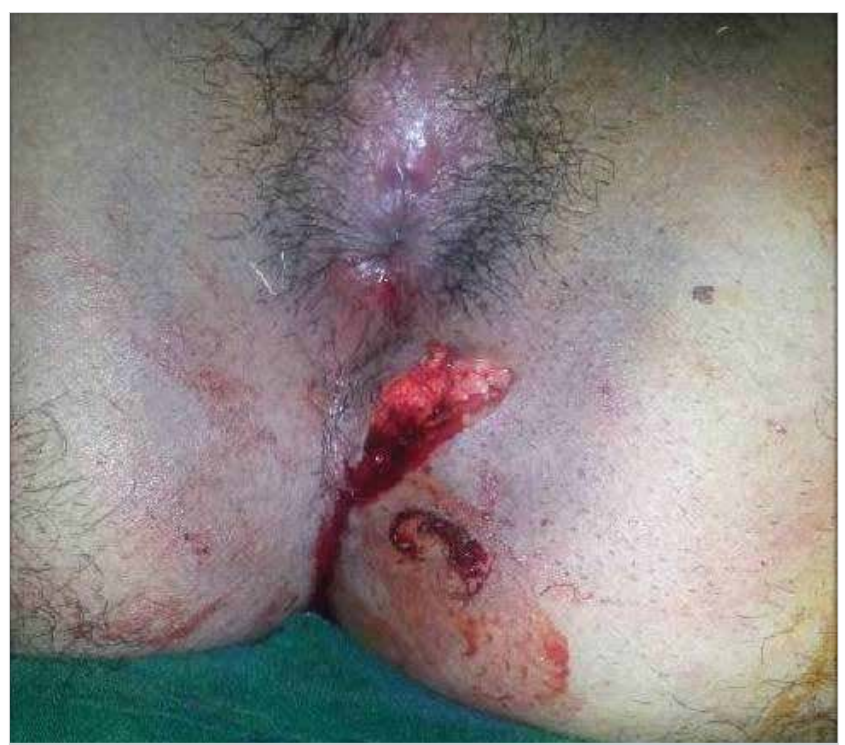

Figure 7. 38-year-old male patient with a case of perianal sinus tract at the level of. 4 o'clock.

ly in 13 cases (16.66\%). Fifty-three patients (67.95\%) presented with chronic discharge, 16 (20.5\%) patients presented with dull aching pain of the distended non-infected cyst and 9 (11.5\%) patients had an acute abscess for which incision and drainage was performed followed by excision and primary closure 3 months later (Table 3).

All of the chronic cases except the one presented with perianal pilonidal sinus underwent excision and tension free primary
Table 4. Postoperative complications

\begin{tabular}{|l|c|}
\hline No -complication & Number of patients (\%) \\
\hline Wound infection & $61(78.2 \%)$ \\
\hline Recurrence & $5(6.46 \%)$ \\
\hline Patient Disappear not follow up & $3(3.8 \%)$ \\
\hline Hematoma & $9(11.54 \%)$ \\
\hline Seroma & $0(0 \%)$ \\
\hline & $0(0 \%)$ \\
\hline
\end{tabular}

closure. Mean time of the operation was 44.6 minutes, ranging between $42-57$ minutes.

One of our cases, a 38-year-old male patient, was referred to us and described as a case of sinus in ano, and during the operation, we found perianal sinus tract at the level of 4 o'clock which was completely excised and proven by histopathology as pilonidal sinus (Figure 7).

Mean length of hospital stay was 2.5 days (range, 2-3 days). Postoperatively, sixty-one (78.2\%) cases were without intraoperative, early or late postoperative complications, 5 (6.41\%) cases had minor wound infection and 3 (3.85\%) obese hairy patients developed recurrence, and 9 (11.54\%) cases could not be reached during follow-up, which was conducted even by phone for cases living in far governorates (Table 4).

\section{DISCUSSION}

Intergluteal pilonidal disease is an infection disease affecting the skin and subcutaneous tissue in the midline of the upper part of the natal cleft of the buttocks (12). If the depth of the intergluteal sulcus increases, it will blead to the increase in anaerobic bacteria and form a good media for growth in this area (13).

In addition, the development of pilonidal disease is thought to be a result of a vacuum effect created between heavy buttocks. The vacuum effect sucks the anaerobic bacteria, hair, and debris into the subcutaneous fat tissue. If these factors responsible for the development of the disease are not eliminated, they will play important roles in the development and recurrence of the disease $(14,15)$.

The mainstay of operative management for chronic or persistent disease is eradication of all pilonidal sinus tracts. En bloc eradication of the entire pilonidal sinus and epithelialized tracts was performed down to the sacrococcygeal fascial level, keeping normal tissue intact as much as possible $(16,17)$.

There are several surgical methods used in the treatment and control of sacrococcygeal pilonidal sinus, however postoperative morbidity could not be reduced by those methods and there is no agreement on the best gold standard method of 
surgical treatment (18). Any procedure should stress well on other parameters than postoperative morbidity and recurrence, such as simple technique, length of hospital stay, and length of absence from work $(17,19)$. Many studies comparing various procedures have documented the relative superiority of one over the other. For simple, non-recurrent pilonidal sinus, less invasive surgery with excision and primary closure could be enough (18).

Primary closure technique is associated with earlier wound healing (complete epithelialization) and a faster return to daily work, but a delayed (open) closure is associated with a lower likelihood of pilonidal disease recurrence $(12,20)$.

The results of our study in which primary closure was tension free boosted these proposal. Patients walked freely without significant pain, but minor wound infection was noted in only 5 cases.

Low morbidity rate of certain surgery techniques is also naturally reflected by hospitalization time and time off work. In some papers reported for tension free primary closure, hospital stay is short and less than 5.5 days as reported by Rossi et al. (1993) for Limberg flap (21) and 5.7 days as reported by Singh et al. (2005) for adipose fasciocutaneus flap $(22,23)$. Hospital stay in this study was shorter than 4 days and time off work was not more than three weeks. A total of 11 trial studies ( $n=1729$ patients) have included data for work return time, where nine studies have reported a faster return time to work following primary closure (24). The largest study including 144 patients has found that patients undergoing a primary repair have a significantly faster rate of return to work as compared to those with open wounds (11.9 versus 17.5 days, respectively) (24). Some authors say that primary closure is better and comfortable, especially in small defects. Excision surgery alone, or Excision and Primary closure of the wound, has been compared in a previous study (25). In addition, post-operative wound importance in this study was considered. Any exercise or sitting down on the wound was avoided for 3 weeks, and the patient was advised to return as slowly as possible to his/her normal activities. Hair-shaving from the edges of the wound is necessary $(26,27)$. Shaving has to be continued for a long time or until complete healing of the wound (27). In this study, during follow-up of 12 months, only three recurrences (\%4.6) in obese, hairy male patients were seen in a total of 65 (83.3\%) patients at 1 year after surgery, which is in agreement with the study by Akinci et al. (1999) stating that pilonidal sinus is an acquired disease, penetration of hair is the main cause, and understanding the causes help prevent the disease (28). Time of healing was shorter after excision and closure, but recurrences occurred more as compared with excision alone. In addition, primary closure has been reported to result in a higher initial primary rate of healing with shorter and a reduced duration of hospital stay (19). For more comparisons with other studies, see Table 5.

\section{Study Limitations}

The limitation to our study includes losing contact with some patients after surgery.

\begin{tabular}{|c|c|c|c|c|c|}
\hline Patients (no.) & Surgical procedure & $\begin{array}{l}\text { Hospital stay } \\
\text { (days) }\end{array}$ & Complication (\%) & Recurrence (\%) & $\begin{array}{l}\text { First author, Year } \\
\text { (Reference) }\end{array}$ \\
\hline 110 & Excision and Limberg flap & 3.7 & 5.88 & 4.9 & (Urhan et al. 2002) (29) \\
\hline 312 & $\begin{array}{l}\text { Excision and primary } \\
\text { closure }\end{array}$ & 2 & 4 & 3 & $\begin{array}{l}\text { (Ciccolo et al. 2004) } \\
\text { (30) }\end{array}$ \\
\hline 238 & $\begin{array}{l}\text { Excision with a Limberg } \\
\text { transposition flap }\end{array}$ & $2.1(1-3)^{*}$ & 0.8 & 1.26 & (Mentes et al. 2004) (31) \\
\hline 25 & Limberg technique & $4^{* *}$ & 16 & 4 & $\begin{array}{l}\text { (Katsoulis, Hibberts, and Carapeti } \\
\text { 2006) (32) }\end{array}$ \\
\hline 411 & Excision and Limberg flap & $3.2(1-10)^{* * *}$ & 16.78 & 2.91 & (Akin et al. 2008) (33) \\
\hline 229 & $\begin{array}{l}\text { Excision and primary } \\
\text { closure }\end{array}$ & $2.1(2-5)^{*}$ & 9.1 & 4.4 & (Toccaceli et al. 2008) (34) \\
\hline 110 & Limberg technique & 3 & 5.5 & 4.9 & $\begin{array}{l}\text { (Aslam, Shoaib, and Choudhry } \\
\text { 2009) (35) }\end{array}$ \\
\hline 60 & Rhomboid flap closure & $6(5-11)^{*}$ & 15 & 10 & (el-Khadrawy et al. 2009) (36) \\
\hline 78 & $\begin{array}{l}\text { Excision and tension-free } \\
\text { primary closure }\end{array}$ & $2.5(2-3)^{*}$ & 5 cases $(6.4 \%)$ & 3 cases $(3.84 \%)$ & Current study \\
\hline
\end{tabular}




\section{CONCLUSION}

Excision and tension-free primary closure of the pilonidal disease is effective with low complication rates, short hospitalization, low recurrence rates, earlier healing and shorter time off work. The surgery can be easily performed. It is now clearly shown that there is better patient satisfaction with primary wound closure rather than leaving it open.

Ethics Committee Approval: Approval from the ethics committee of our hospital was obtained.

Informed Consent: Not required in this study.

Peer-review: Externally peer-reviewed.

Author Contributions: Concept - M.A.; Design - M.A.; Supervision - M.A.; Resource - M.A.; Materials - M.A.; Data Collection and/or Processing - M.A., A.M.; Analysis and/or Interpretation - M.A., A.M.; Literature Search - M.A.; Writing Manuscript - M.A.; Critical Reviews - M.A.

Conflict of Interest: The authors have no conflicts of interest to declare.

Financial Disclosure: The authors have no conflicts of interest to declare.

\section{REFERENCES}

1. Hodges R. Pilonidal sinus. Boston Med Surg J 1880:485-586. [CrossRef]

2. Bertelsen CA. Cleft-lift operation for pilonidal sinuses under tumescent local anesthesia: a prospective cohort study of peri- and postoperative pain. Diseases of the Colon \& Rectum 2011;54(7):895-900. [CrossRef]

3. Surrell JA. Pilonidal disease. Surg Clin North Am 1994;74(6):1309-15. [CrossRef]

4. Sondenaa K, Andersen E, Nesvik I, Soreide JA. Patient characteristics and symptoms in chronic pilonidal sinus disease. Int J Colorectal Dis 1995;10(1):39-42. [CrossRef]

5. 5Karaca AS, Ali RR, Çapar M, Karaca S. Comparison of Limberg flap and excision and primary closure of pilonidal sinus disease, in terms of quality of life and complications. Journal of the Korean Surgical Society 2013;85(5):236-9.[CrossRef]

6. Kumar S, Haboubi N, Chintapatla S, Safarani N. Sacrococcygeal pilonidal sinus: historical review, pathological insight and surgical options. Techniques in Coloproctology 2003;7(1):3-8.[CrossRef]

7. Lee HC, Ho YH, Seow CF, Eu KW, Nyam D. Pilonidal disease in Singapore: clinical features and management. The Australian and New Zealand Journal of Surgery 2000;70(3):196-8.[CrossRef]

8. Müller K, Marti L, Tarantino I, Jayne DG, Wolff K, Hetzer FH. Prospective analysis of cosmesis, morbidity, and patient satisfaction following limberg flap for the treatment of sacrococcygeal pilonidal sinus. Diseases of the Colon \& Rectum 2011;54(4):487-94.[CrossRef]

9. Shafik A. Electrocauterization in the treatment of pilonidal sinus. Intern Surg 2017;81(1):83-4.

10. Duchateau J, De Mol J, Bostoen H, Allegaert W. Pilonidal sinus. Excision--marsupialization--phenolization? Acta Chirurgica Belgica 2017;85(5):325-8.

11. World Health Organization. BMI classification. Pharmacotherapy 2006:4-9.
12. Khanna A, Rombeau J. Pilonidal Disease. Clinics in Colon and Rectal Surgery [Internet]. 2011 Mar 23 [cited 2018 May 10];24(1):04653. Available from: http://www.thieme-connect.de/DOI/DOI? 10.1055/s-0031-1272823 [CrossRef]

13. Miocinović M, Horzić M, Bunoza D. The prevalence of anaerobic infection in pilonidal sinus of the sacrococcygeal region and its effect on the complications. Acta medica Croatica : casopis Hravatske akademije medicinskih znanosti. 2001;55(2):87-90.

14. Bascom J. Pilonidal disease: origin from follicles of hairs and results of follicle removal as treatment. Surgery. 1980;87(5):567-72.

15. Schoeller T, Wechselberger G, Otto A, Papp C. Definite surgical treatment of complicated recurrent pilonidal disease with a modified fasciocutaneous V-Y advancement flap. Surgery. 1997;121(3):258-63. [CrossRef]

16. Bascom J. Pilonidal disease: long-term results of follicle removal. Diseases of the Colon and Rectum 1983;26(12):800-7.[CrossRef]

17. Oncel M, Kurt N, Kement M, ColakE, Eser M, Uzun H. Excision and marsupialization versus sinus excision for the treatment of limited chronic pilonidal disease: a prospective, randomized trial. Techniques in Coloproctology 2002;6(3):165-9. [CrossRef]

18. Saber A. Evidence-based management of sacrococcygeal pilonidal sinus. Jurnalul de Chirurgie. OMICS International; 2014;10(1):1-4.

19. Petersen S, Koch R, Stelzner S, Wendlandt TP, Ludwig K. Primary closure techniques in chronic pilonidal sinus: a survey of the results of different surgical approaches. Diseases of the Colon and Rectum 2002;45(11):1458-67.[CrossRef]

20. Lee HC, Ho YH, Seow CF, Eu KW, Nyam D. Pilonidal disease in Singapore: clinical features and management. Aust N Z J Surg 2000;70(3):196-8. [CrossRef]

21. Rossi P, Russo F, Gentileschi P, Quintigliano D, Cicardo G, Nasrollah N, et al. The pilonidal sinus: its surgical treatment, our experience and a review of the literature. II Giornale di Chirurgia 1993;14(2):120-3.

22. Singh R, Pavithran NM. Adipo-fascio-cutaneous flaps in the treatment of pilonidal sinus: experience with 50 cases. Asian J Surg 2005;28(3):198-201. [CrossRef]

23. Morell V, BL C, Deshmukh N. Surgical treatment of pilonidal disease: comparison of three different methods in fifty-nine cases. Military Medicine 1991;156(3):144-6. [CrossRef]

24. Fazeli MS, Adel MG, Lebaschi AH. Comparison of outcomes in Z-plasty and delayed healing by secondary intention of the wound after excision of the sacral pilonidal sinus: results of a randomized, clinical trial. Diseases of the Colon and Rectum 2006;49(12):1831-6. [CrossRef]

25. Kronborg O, Christensen K, Zimmermann-Nielsen C. Chronic pilonidal disease: a randomized trial with a complete 3-year follow-up. Br J Surg 1985;72:303-4.[CrossRef]

26. Jamal A, Shamim M, Hashmi F, Qureshi MI. Open excision with secondary healing versus rhomboid excision with Limberg transposition flap in the management of sacrococcygeal pilonidal disease. JPMA 2009;59(3):157-60.

27. Hull TL, Wu J. Pilonidal disease. Surg Clin North Am 2002;82(6):1169-85. [CrossRef]

28. Akıncı F, Mikda Ö, Bozer M, Uzunköy A, Düzgün SA, Coşkun A, et al. Incidence and aetiological factors in pilonidal sinus among Turkish soldiers. Eur J Surg 1999;165(4):339-42.[CrossRef]

29. Urhan MK, Kücükel F, Topgul K, Ozer I, Sari S. Rhomboid excision and Limberg flap for managing pilonidal sinus: results of 102 cases. Diseases of the Colon and Rectum 2002;45(5):656-9.[CrossRef] 
30. Ciccolo A, Rossitto M, Panacea D, Manfrè A, Buonamonte S, Ardizzone A. Treatment of pilonidal disease in short-stay surgery: personal method. Annali Italiani di Chirurgia 2004;75(5):603-5.

31. Mentes BB, Leventoglu S, Cihan A, Tatlicioglu E, Akin M, Oguz M. Modified limberg transposition flap for sacrococcygeal pilonidal sinus. Surgery Today 2004;34(5):419-23.[CrossRef]

32. Katsoulis IEE, Hibberts F, Carapeti EAA. Outcome of treatment of primary and recurrent pilonidal sinuses with the Limberg flap. Surgeon 2006;4(1):7-10. [CrossRef]

33. Akin M, Gokbayir H, Kilic K, Topgul K, Ozdemir E, Ferahkose Z. Rhomboid excision and Limberg flap for managing pilonidal sinus: longterm results in 411 patients. Colorectal Disease 2008;10(9):945-8. [CrossRef]
34. Toccaceli S, Persico Stella L, Diana M, Dandolo R, Negro P. Treatment of pilonidal sinus with primary closure. A twenty-year experience. Chir Ital 2008;60(3):433-8

35. Aslam MN, Shoaib S, Choudhry AM. Use of Limberg flap for pilonidal sinus--a viable option. Journal of Ayub Medical College 2009;21(4):313.

36. el-Khadrawy O, Hashish M, Ismail K, Shalaby H. Outcome of the rhomboid flap for recurrent pilonidal disease. World J Surg 2009;33(5):1064 8.[CrossRef]

\section{ORIJINAL ÇALIŞMA-ÖZET}

Turk J Surg 2019; 35 (4): 278-284

\section{Pilonidal hastalıkta eksizyon ve gerilimsiz primer kapanma}

Mohamed A. Alkatta, Abdallah Mejally

Sanáa Üniversitesi, Cerrahi Bölümü, Sana'a, Yemen

\section{ÖZET}

Giriş ve Amaç: Bu çalışmanın amacı, basit eksizyon ve gerilimsiz primer kapamayı değerlendirmek ve operasyon ve iyileşme süresi, hastanede kalış süresi, postoperatif komplikasyon derecesi ve tekrarlama oranındaki etkisini incelemekti.

Gereç ve Yöntem: Çalışmaya 71'i erkek (\%91) ve 7'si kadın olmak üzere eksizyon ve gerilimsiz primer kapama cerrahi işlemi geçiren toplam 78 hasta dahil edildi. Cerrahi işlem, yara kenarından salınıp 2-3 cm kadar diseke edilen bilateral taraflı flepler ile gerçekleştirildi. Hastaların yaşı, cinsiyeti, vücut kitle indeksi, yara iyileşmesi, operasyon, drenin çıkarılması, hastanede kalış süresi, komplikasyonlar ve rekürrans analiz edildi.

Bulgular: Çalışmaya 71'i erkek (\%91) ve 7'si kadın (\%9) olmak üzere toplam 78 hasta dahil edildi. Hastaların ortanca yaşı 28,5 yıldı. Ortalama operasyon süresi 44,6 dakika idi. Altmış bir hastada $(\% 78,2)$ herhangi bir komplikasyon olmaksızın tam primer iyileşme gözlemlendi. Hiçbir hastada hematom veya seroma gelişmedi, ancak beş olguda $(\% 6,4)$ hafif yara enfeksiyonu ve üç obez hastada $(\% 3,8)$ rekürrens oluştu. Ortalama hastanede kalış süresi 2,5 gündü ve çoğu hasta 3 hafta içerisinde çalışma hayatlarına geri döndü. Ortanca takip süresi 26,2 haftalık bir aralık içerisindeyd (1-51,4 hafta). Beş hastada $(\% 6,41)$ yara enfeksiyonu, üç hastada da $(\% 3,85)$ rekürrens vardı.

Sonuç: Eksizyon ve gerilimsiz primer kapama, daha düşük yara enfeksiyonu oranı, daha kısa hastanede kalış süresi, daha düşük rekürrens, erken yara iyileşmesi ve iş hayatından kısa süreli uzaklaşma ile ilişkili basit operasyonlardır. Cerrahi müdahale kolaylıkla yapılabildiği gibi nüks olmayan pilonidal sinüs ve kist olgularında tercih edilen cerrahi işlem olabilir.

Anahtar Kelimeler: Pilonidal, primer kapama, natal kleft sinüs, kist

Doi: $10.5578 /$ turkjsurg.4368 